Ubell, science editor, New York Herald Tribune, who also is vice-president of the National Association of Science Writers ; Vice-president, W. Bradford Wiley, president of John Wiley and Sons; and Secretary Treasurer, Prof. Hillier Krieghbaum, Harvard University. Further information can be obtained from the Department of Journalism, New York University.

\section{Scales of Temperature in the Meteorological Office}

THE Director-General of the Meteorological Office has decided that from January 1, I961, the celsius (centigrade) scale of temperature will be used for all work carried out within the Office. At present, the Fahrenheit scale is used for surface observations (air temperature, dewpoint, soil and Earth temperatures); the change to the celsius scale for aerological work having been made some time ago. The decision to employ only the celsius scale in professional work is in line with the recommendations of the World Meteorological Organization, and its adoption not only brings the Meteorological Office into line with all other European services but also will greatly facilitate the international exchange of meteorological information. The change will affect only the internal practice of the Meteorological Office, and at present there is no intention to remove the degree Fahrenheit from the published forecasts, or from replies to inquiries.

\section{Sudan Natural History Museum, Khartoum}

THE report for $1956-58$ of the Natural History Museum, Khartoum, is the first to be published since the control of this institution was assumed by the University. Since its formation in the 1920's the Museum has had a chequered career, and it was only recently that it passed to the University of Khartoum. This association has enabled the Museum to draw freely on the specialized knowledge of the University staff and to develop according to a deliberate longterm policy. On the other hand, the Biological Department of the University benefits considerably by easier access to the technical skill and knowledge possessed by the staff of the Museum. It also enables the staff of the University to use freely the collections and records in the Museum for teaching and research. The constitution of the Board for the Natural History Museum still awaits the adoption of a statute by the University Council; but this formality has not prevented full co-operation for some time past.

\section{Communicable Diseases in School}

Communicable diseases are one of the commonest causes of school absenteeism. A survey by the World Health Organization examines the statutory rogulations in force in fifteen countries (Geneva. $3 s .6 d$. ). The measures prescribed, of which the exelusion from school of sick children and of contacts is paramount, are compared with the recommendations found in medical literature. Health authorities tend at presont to substitute surveillance for stringent measures. Surveillance presupposes well-organized school health services and the existence of bacteriological laboratories. The subject-matter of the study published in the report is arranged under the following headings : legislation, exclusion measures, obligations of parents, teaching staff and health services; measures relating to school staff; and closure of schools. An appendix contains an analysis in tabular form, by country and by disease, of the statutory measures taken in countries the legislation of which is covered by the study.
It is surprising to find that there is virtually no uniformity whatever in the measures prescribed for dealing with the occurrence in schools of diseases the epidemiology, evolution and method of spread of which are well known.

\section{Caroline Haslett Exhibition for a Woman Engin- eer}

The Caroline Haslett Memorial Trust announces that the first award to be made by the General Section of the Trust will be an exhibition to enable a woman engineer to visit the U.S.S.R. for the purpose of studying the training, employment and prospects of Soviet women engineers. Applications for the exhibition are invited from women engineers in the United Kingdom whose training and experience would fit them to make the proposed study. The visit will be a short one and will probably take place in the early autumn of this year. After her return to Great Britain the exhibitioner will be required to prepare a report for the Trust and to lecture on her findings. The Caroline Haslett Memorial Trust was established in 1958 to commemorate the work of the late Dame Caroline Haslett. Application forms, which should be returned before March 31, can be obtained from the Secretary, Caroline Haslett Memorial Trust, 25 Foubert's Place, London, W.1.

\section{Horticultural Co-operative Marketing Societies}

THE Minister of Agriculture, Fisheries and Food, the Rt. Hon. John Hare, is setting up a departmental Working Party "To consider and report on the methods and forms of association between horticultural co-operative marketing societies and their mombers, and whether these might be modified so as to give the societies more stability and continuity in their supplies of produce". Mr. J. B. Godber, joint parliamentary secretary to the Ministry, will be chairman of the Working Party, and it is expected to have its first meeting in mid-March. It will seek evidence from the agricultural co-operative associations and their constituent societies on the horticultural side, and from other persons with a direct knowledge of the subject.

\section{University News :}

Bristol

THE following are announced: Appointments, to become lecturer in aeronautical engineering, $\mathrm{Mr}_{\mathrm{r}}$. J. W. Flower ; to become senior lecturer in physics, Dr. W. M. Gibson. Grants, from the Department of Scientific and Industrial Research, $£ 15,000$ for an electron microscope, and $£ 3,850$ for an investigation in the Department of Physical and Inorganic Chemistry on the electronic spectra of ionized hydrocarbons; from the Royal Society, $£ 2,291$ to the Department of Physical and Inorganic Chemistry for the purchase of a high-temperature resistance vacuum furmace in connexion with investigations on the synthesis and chemical properties of carbides, silicides, borides and phosphides of metals. Biological material to the value of $£ 2,800$ has been received by the Department of Pharmacology from the Bingham Oceanographic Laboratories, Yale University.

\section{Cambridge}

The Council of St. John's College, Cambridge, will make a Kenneth Craik Research Award for the assistance of persons engaged in postgraduate rosearch. preferably in physiological psychology. The value of 